\title{
RARE PENILE KELOID AFTER CIRCUMCISION: CASE REPORT AND LITERATURE REVIEW
}

\author{
Muhammad Izzuddin Hamzan, ${ }^{1,2}$ Mohamad Jeremi Jeffrey, ${ }^{1,2}$ Ahmad Sukari Halim ${ }^{1,2}$ \\ ${ }^{1}$ Reconstructive Science Unit, School of Medical Sciences, Universiti Sains Malaysia, Kota Bharu, Malaysia \\ ${ }^{2}$ Hospital Universiti Sains Malaysia, Health Campus, Universiti Sains Malaysia, Kota Bharu, Malaysia
}

Primljen/Received 01. 04. 2020. god.

Abstract: Objective: To report a case of keloid formation after circumcision and review the literature for similar cases to formulate possible risk factors contributing to its development as well as its treatment options.

Method: a literature review was done using PubMed and Google Scholar by searching the keyword "keloid", "penis" and "circumcision". Additional searches were done on references from related articles. The articles are then reviewed by the author, noting for possible predisposing factors to keloid formation, along with patient demographics and method of treatments. Findings were then tabulated and analyzed using Microsoft Excel (2018).

Results: Thirteen case reports on penile keloid after circumcision with a total of 16 patients were found dating from 1993 to 2017. Circumcision in four cases $(25 \%)$ were complicated with infection or dehiscence. The median age during circumcision is 9 years old. Two patients (12.5\%) were reported with the tendency for keloid. The ethnicity of the patients is as follows; Turkish ( 7 cases, 43.7\%), African descent (4 cases, $25 \%$ ), Chinese (3 cases, 18.75\%), Indian (1 case $6.25 \%)$ and Caucasian (1 case, $6.25 \%)$. Ten $(62.5 \%)$ cases were treated with a combination of excision and immediate injection of triamcinolone acetate. Others were treated with either excision alone, steroid injection alone or excision with topical steroid. Maintenance treatment includes topical steroid, intralesional injection of steroid, and silicone gel. Recurrence occurred in one patient.

Conclusion: The minuscule number of published reports of keloid formation after circumcision underscores the rarity of the complication. No specific risk factors can be attributed to stratify patients who may develop keloid after circumcision. Excision followed by triamcinolone acetate injection with maintenance
Prihvaćen/Accepted 20. 05. 2020. god.

therapy until scar maturity is the preferred choice of treatment for penile keloid.

Keywords: Penile keloid, circumcision, keloidal scar.

\section{INTRODUCTION}

Excision of the penile foreskin, is one of the most frequently performed surgeries in men. It is projected that one-third of the total male population is circumcised (1). While there is no official data on the prevalence of circumcision in Malaysian men, it is estimated that at least $60 \%$ of Malaysian men are circumcised as it reflects the proportion of Muslim men in the country. It is performed due to various reasons, commonly due to religious beliefs and cultural rites. Medically, it is indicated for paraphimosis, balanitis and balanoposthitis and for the prevention of HIV and other sexually transmitted infections in a high-risk population (2).

Complications rates vary between regions and the age of circumcision. Common complications include bleeding, infection, wound dehiscence, and excess skin removal. Iatrogenic glans amputation is an uncommon but a severely debilitating complication (3). While the general understanding is that the penile skin heals well with favorable scarring, there has been a handful of anecdotal reports of pathological scarring, either hypertrophic or keloid scar stemming from circumcision. We report such a case, which to the best of our knowledge, the first in the Southeast Asian population.

\section{CASE PRESENTATION}

A 14 years old boy who is under our follow-up for keloid scar over his left pre-auricular region presents with a painless, rubbery nodule along his circumcision scar which was performed 3 years ago. He also carries a strong familial history of developing a keloid scar, 


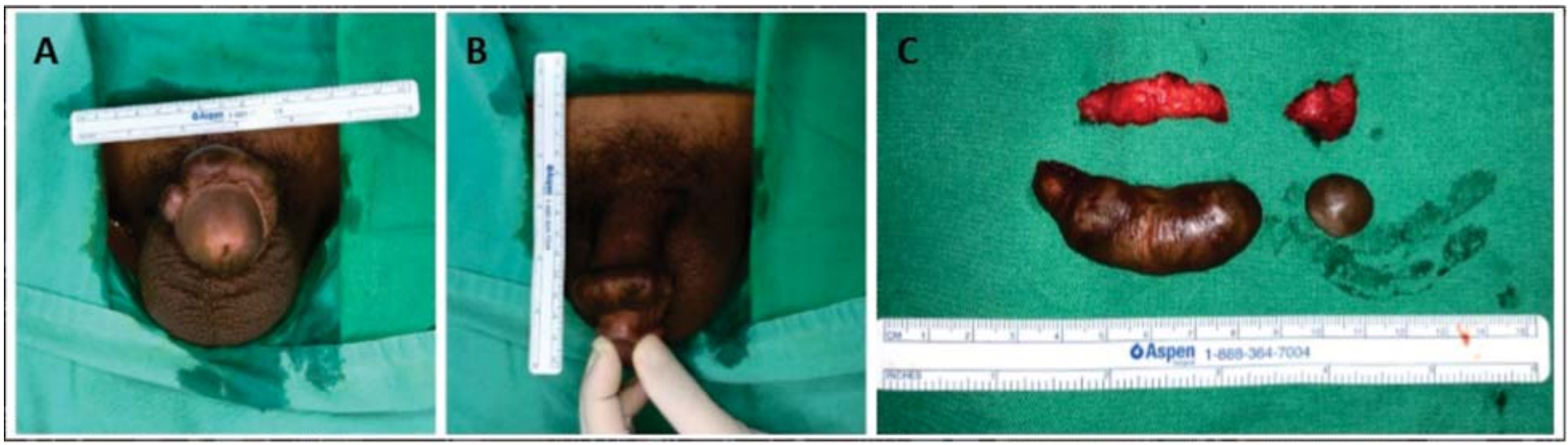

Figure 1. A: two keloidal nodule scar from front view; B: dorsal aspect of penile keloid; and $C$ : excised keloidal scar shown with its measurement

claiming some males from the paternal side, including his brother. The circumcision was performed concurrently with excision of keloid scar over his left pre-auricular region at our center. Recovery following surgery was uneventful. While it is uncertain when the nodule appears following circumcision, it was claimed by the patient that it steadily increases in size.

Physical examination revealed two rubbery, mobile, non-tender nodules along the dorsal aspect of his circumcision scar (Figure 1A). It measures $5 \times 2 \times 2 \mathrm{~cm}$ and $1.5 \times 1.5 \times 2 \mathrm{~cm}$ (Length $\times$ Width X Height) (Figure 1B). The ventral aspect of the circumcision wound otherwise forms a hairline scar which is expected from an uncomplicated circumcision. The nodule was excised completely (Figure 1C) and closed tension-free with subdermal undyed Vicryl 5-0 and subcuticular Prolene 5-0. Suture removal (Prolene) was done on day 5 post-operation. Triamcinolone acetate injection was commenced at 2 weeks following surgery and scheduled for every six weeks until the scar fully matures. Histological examination revealed nodules of haphazardly arranged broad homogenous collagen bundles. Fibroblasts are seen arranged parallel to these collagen bundles. A moderate amount of lymphoplasmacytic cells are present in the dermis. These findings are consistent with keloid.

\section{Literature Review}

A literature search was done via PubMed and Google Scholar using the keywords "keloid", "penis" and "circumcision". A total of 20 abstracts of relevant articles were found. Full-text articles were available to the author for all except one. A secondary search was performed on references from related articles. Only articles of keloid formation after circumcision are included for analysis. Information on patient's ethnicity (Table 1), age at presentation, age of circumcision, family history/self -tendency to develop keloid scar, treatment methods and recurrence were tabulated and analyzed using Excel. Articles with missing data were excluded from the relevant analysis.

\section{RESULTS}

There is a total of 16 patients spreading across 13 articles (Table 2) with the earliest report was published in 1993 and the latest in 2017. Data on 4 patients were incomplete for age at circumcision and 3 patients were incomplete for the tendency for keloid scarring.

Out of 16 patients, 4 (25\%) suffered complications following circumcision. In 13 patients in which family history/tendency to develop keloid scar was explored, $2(15.4 \%)$ reports having a tendency for keloid scarring. The majority of the author's employed a multimodal approach to penile keloid treatment $(68.75 \%)$. Intralesional injection of triamcinolone is the preferred choice $(80 \%)$ by most authors who opted for a single modality approach. Regardless of the treatment method, recurrence was reported in one case in which excision and triamcinolone injection were employed.

Table 1. Demographics of patients with keloid formation after circumcision

\begin{tabular}{|c|c|c|}
\hline \multicolumn{2}{|c|}{$\begin{array}{l}\text { Median Age of Circumcision, Years (Youngest, Oldest) } \\
\text { Median Age at Presentation, Years (Youngest, Oldest) } \\
\text { Family History/Tendency for Keloid }\end{array}$} & $\begin{array}{c}9(3,31) \\
9.5(13 \text { months, } 32 \text { years }) \\
2 \text { of } 10 \text { cases }\end{array}$ \\
\hline Ethnicity & $\begin{array}{c}\text { Turkish } \\
\text { African Descent } \\
\text { Chinese } \\
\text { Indian } \\
\text { Caucasian }\end{array}$ & $\begin{array}{c}6 \text { reports } \\
4 \text { reports } \\
3 \text { reports } \\
1 \text { report } \\
1 \text { report }\end{array}$ \\
\hline
\end{tabular}


Table 2. Reports on keloid formation after circumcision and its treatment

\begin{tabular}{|c|c|c|c|c|c|c|c|c|}
\hline & Author, Year & Ethnicity & Age & $\begin{array}{c}\text { Age at } \\
\text { Circumcision }\end{array}$ & Complications & $\begin{array}{l}\text { Keloid } \\
\text { tendency }\end{array}$ & Treatment & Recurrence \\
\hline 1 & \begin{tabular}{|c|} 
Warwick et al, \\
$1993(4)$
\end{tabular} & $\begin{array}{l}\text { African } \\
\text { descent }\end{array}$ & $10 \mathrm{yrs}$. & $12 \mathrm{yrs}$. & No & Not stated & $\begin{array}{l}\text { Intralesional } \\
\text { triamcinolone }\end{array}$ & No \\
\hline 2 & $\begin{array}{c}\text { Gurunluoglu et } \\
\text { al, 1996(5) }\end{array}$ & Turkish & 12 yrs. & 9 yrs. & No & Yes & $\begin{array}{l}\text { Intralesional } \\
\text { triamcinolone }\end{array}$ & No \\
\hline 3 & $\begin{array}{c}\text { Gurunluoglu et } \\
\text { al, 1997(6) }\end{array}$ & Turkish & 13 yrs. & - & No & Not stated & $\begin{array}{l}\text { Intralesional } \\
\text { triamcinolone }\end{array}$ & No \\
\hline 4 & $\begin{array}{c}\text { Bekerecioglu et } \\
\text { al, 2005(7) }\end{array}$ & Turkish & $13 \mathrm{yrs}$. & 8 yrs. & No & No & $\begin{array}{c}\text { Excision }+ \\
\text { triamcinolone } \\
\text { injection }\end{array}$ & No \\
\hline 5 & $\begin{array}{l}\text { Erdemir et al, } \\
2006(8)\end{array}$ & Turkish & $15 \mathrm{yrs}$. & $14 \mathrm{yrs}$. & No & No & $\begin{array}{l}\text { Excision }+ \\
\text { triamcinolone } \\
\text { injection }\end{array}$ & No \\
\hline 6 & $\begin{array}{l}\text { Isken et al, } \\
2008(9)\end{array}$ & Turkish & $10 \mathrm{yrs}$. & 8 yrs. & No & Not stated & $\begin{array}{c}\text { Topical steroid } \\
\text { followed by } \\
\text { excision }\end{array}$ & No \\
\hline 7 & $\begin{array}{c}\text { Lokhande et al, } \\
2010(10)\end{array}$ & Indian & 9 yrs. & 9 yrs. & No & No & $\begin{array}{c}\text { Excision }+ \\
\text { triamcinolone }\end{array}$ & No \\
\hline 8 & $\begin{array}{c}\text { Demirdover et } \\
\text { al, 2012(11) }\end{array}$ & Turkish & 3 yrs. & 3 yrs. & No & No & $\begin{array}{l}\text { Intralesional } \\
\text { triamcinolone } \\
\text { followed by } \\
\text { excision }\end{array}$ & No \\
\hline 9 & $\begin{array}{l}\text { Xie et al, } \\
2013(12)\end{array}$ & Chinese & 32 yrs. & $31 \mathrm{yrs}$. & Infection & Yes & $\begin{array}{l}\text { Excision }+ \\
\text { triamcinolone } \\
\text { injection }\end{array}$ & No \\
\hline 10 & & Chinese & $10 \mathrm{yrs}$. & 8 yrs. & Infection & No & $\begin{array}{c}\text { Excision }+ \\
\text { triamcinolone } \\
\text { injection }\end{array}$ & No \\
\hline 11 & & Chinese & $12 \mathrm{yrs}$. & $12 \mathrm{yrs}$. & Infection & No & $\begin{array}{c}\text { Excision }+ \\
\text { triamcinolone } \\
\text { injection }\end{array}$ & No \\
\hline 12 & $\begin{array}{l}\text { Yong et al, } \\
2013(13)\end{array}$ & $\begin{array}{l}\text { African } \\
\text { descent }\end{array}$ & 19 months & - & Dehiscence & No & Excision & No \\
\hline 13 & $\begin{array}{c}\text { Cinpolat et al, } \\
2015(14)\end{array}$ & Turkish & 9 yrs. & 9 yrs. & No & No & $\begin{array}{c}\text { Excision }+ \\
\text { triamcinolone } \\
\text { injection }\end{array}$ & No \\
\hline 14 & $\begin{array}{l}\text { Ozinko et al, } \\
2015(15)\end{array}$ & Nigerian & 13 months & - & No & No & $\begin{array}{l}\text { Intralesional } \\
\text { triamcinolone }\end{array}$ & No \\
\hline 15 & & Nigerian & 2 yrs. & - & No & No & $\begin{array}{l}\text { Excision }+ \\
\text { triamcinolone } \\
\text { injection }\end{array}$ & $\begin{array}{c}\text { Yes, } \\
\text { Re-excised + } \\
\text { triamcinolone }\end{array}$ \\
\hline 16 & $\begin{array}{l}\text { Sanal et al, } \\
\text { 2017(16) }\end{array}$ & Caucasian & $13 \mathrm{yrs}$. & $11 \mathrm{yrs}$. & No & No & $\begin{array}{c}\text { Excision }+ \\
\text { triamcinolone } \\
\text { injection }\end{array}$ & No \\
\hline
\end{tabular}

Table 3. Published approach to penile keloid

\begin{tabular}{|c|c|c|c|}
\hline \multicolumn{2}{|c|}{ Single Modality Approach } & \multicolumn{2}{|l|}{ Multimodal Approach } \\
\hline Intralesional triamcinolone & $80 \%(4)$ & Excision + intralesional triamcinolone & $81.8 \%(9)$ \\
\hline Excision & $25 \%(1)$ & $\begin{array}{l}\text { Topical steroid followed by excision } \\
\text { Intralesional triamcinolone followed by excision }\end{array}$ & $\begin{array}{l}9 \%(1) \\
9 \%(1)\end{array}$ \\
\hline
\end{tabular}




\section{DISCUSSION}

The majority of patients reported presents with age within the range at which the occurrence of a keloid scar is most common (age 10 to 30 years old). This is further supported by the fact that the occurrence of keloid is linked with a period of a hormonal event such as puberty and pregnancy(17). Therefore, circumcision during the period of puberty may have led some of the published cases to develop keloid after circumcision.

A complicated course of recovery following circumcision, such as infection and dehiscence may not be a major factor in the formation of a keloid scar. The reported rate of such complications varies from $0.0034 \%$ to $7.4 \%$ in populations where circumcision is a common practice (3). Where else, keloid formation, judging from the minuscule number of reports, is almost negligible and does not demonstrate a cause-and-effect relationship with complicated circumcision wounds.

While certain ethnicity such as African and Chinese are more susceptible to developing keloids in general, the same is not reflected in the occurrence of penile keloid after circumcision. Not known to be a population susceptible to keloid, the high number of reports of the formation of keloids after circumcision originating from Turkey may be due to different factors entirely. The differences in the prevalence of keloid scar in general, or perhaps in a different region of the body between ethnicities highlight the role of multiple genetic risk factors as suggested by A.S. Halim et al (2012)(18). In regard to the case being reported, the patient has a history of developing a keloidal scar and carries a strong familial history of keloid. In retrospect, these factors should be taken into account prior to circumcision and with anticipation of keloid formation, should be closely observed for its development with early interven- tion or consider a prophylactic injection of triamcinolone immediately the following circumcision.

Considering the size of the keloid nodule, it is without a doubt that it will incur a functional problem once the patient is sexually active. While the patient did not express any psychological distress caused by the scar, it remains a potential cause for impaired self-esteem as his sexuality matures. Therefore, the objective of our treatment is immediate excision of the keloid scar and prevention of recurrence. All of the published treatment methods were effective in addressing the penile keloid scar (Table 3). Excision and concurrent injection of triamcinolone is the popular method published, however, we opted for delayed injection of triamcinolone to allow for proper wound healing to take place and not risk wound dehiscence by altering the wound healing process.

\section{Conclusion}

The minuscule number of published reports of keloid formation after circumcision underscores the rarity of the complication. No definite risk factors can be recognized to stratify patients who may develop keloid following circumcision. Excision followed by triamcinolone acetate injection with maintenance therapy until scar maturity is the preferred choice of treatment for penile keloid.

Declaration of patient consent: The authors certify that they have obtained all appropriate patient consent forms.

Conflict of Interests: The authors declare that there are no conflicts of interest related to this article.

Funding: None

\section{Licensing}

This work is licensed under a Creative Commons Attribution 4.0 International (CC BY 4.0) License.

\title{
Sažetak
}

\section{RETKI PENILNI KELOIDI NAKON CIRKUMCIZIJE: PRIKAZ SLUČAJA I PREGLED LITERATURE}

\author{
Muhammad Izzuddin Hamzan, ${ }^{1,2}$ Mohamad Jeremi Jeffrey, ${ }^{1,2}$ Ahmad Sukari Halim ${ }^{1,2}$ \\ ${ }^{1}$ Reconstructive Science Unit, School of Medical Sciences, Universiti Sains Malaysia, Kota Bharu, Malaysia \\ ${ }^{2}$ Hospital Universiti Sains Malaysia, Health Campus, Universiti Sains Malaysia, Kota Bharu, Malaysia
}

Cilj: Prikazati slučaj keloida formiranog nakon cirkumcizije i pregled literature za slične slučajeve kako bi se formulisali mogući faktori rizika koji doprinose njihovom razvoju, kao i mogućnosti lečenja.

Metode: Pregled literature je izveden PubMed i Google Scholar pretraživanjem reči „keloid“, „penis“ i „cirkumcizija“. Dodatna pretraživanja su izvedena iz referenci relevantnih članaka. Članci su zatim pregle- dani od strane autora, izdvajajući moguće predisponirajuće faktore za formaciju keloida, zajedno sa demografskim osobinana pacijenata i metoda lečenja. Podaci su zatim tabelirani i analizirani pomoću programa Microsoft Excel (2018).

Rezultati: Trinaest slučajeva prikaza penilnih keloida nakon cirkumcizije kod ukupno 16 pacijenata je nađeno u periodu od 1993 do 2017. Cirkumcizija u četiri 
slučaja (25\%) je komplikovana infekcijom i dehiscencijom. Prosečan uzrast tokom cirkumcizije je 9 godina.

Dva pacijenta (12.5\%) su zabeležena sa sklonošću za keloide. Etnička pripadnost pacijenata je sledeća; tursko (7 slučajeva, 43.7\%), afričko poreklo (4 slučaja, $25 \%$ ), kinesko (3 slučaja, 18.75\%), indijsko (1 slučaj $6.25 \%$ ) i kavkazko poreklo (1 slučaj, 6.25\%). Deset $(62.5 \%)$ slučajeva je lečeno kombinacijom ekscizije i neposrednog ubrizgavanja triamcionolon acetata. Ostali su bili lečeni samo sa ekscizijom, injekcijom steroida ili ekscizijom sa topikalnim steroidima. Terapija održavanja je uključivala topikalne steroide, intra-

\section{REFERENCES}

1. Weiss H, Polonsky J, Bailey R, Hankins C, Halperin D, Schmid G. Male Circumcision: Global trends and determinants of prevalence, safety and acceptability. WHO Press. 2007.

2. Malone P, Steinbrecher H. Medical aspects of male circumcision. BMJ. 2007; 335(7631): 1206-9.

3. Krill AJ, Palmer LS, Palmer JS. Complications of circumcision. Sci World J. 2011; 11: 2458-68.

4. Warwick DJ, Dickson WA. Keloid of the penis after circumcision. Postgr Med J. 1993; 69: 236-7.

5. Gurunluoglu R, Bayramicli M, Numanoglu A. Keloid of the penis after circumcision. Br J Plast Surg. 1996; 49(6): 425-6.

6. Gurunluoglu R, Bayramicli M, Numanoglu A. Two Patients with penile keloids: a review of the literature. Ann Plast Surg. 1997; 39(6): 662-5.

7. Bekerecioglu M, Inaloz HS, Tercan M, Isik D. Keloid formation on an inconspicuous penis. J Dermatol. 2005; 32(10): 835-8.

8. Erdemir F, Parlaktas BS, Sanli O, Kadioglu A, Parlaktas BS, Uluocak $\mathrm{N}$ et al. A rare complication after circumcision: Keloid of the penis. Int Urol Nephrol. 2006; 38(3-4): 609-11.

9. Isken T, Sen C, Isil E, Iscen D, Sozubir S,Gurbuz Y. A very rare complication: keloid formation after circumcision, and its treatment. J Plast Reconstr Aesthetic Surg. 2008; 61(11): 1405-7. lezione injekcije steroida i silikonski gel. Recidiv se javio kod jednog pacijenta.

Zaključak: Minimalan broj objavljenih prikaza keloida formiranih nakon cirkumcizije naglašava retkost komplikacije. Nijedan specifičan faktor rizika ne može biti pripisan grupi pacijenata koji su razvili keloid nakon cirkumcizije. Ekscizija praćena injekcijom triamcionolon acetata sa terapijom održavanja do sazrevanja ožiljka je najčešći izbor za lečenje penilnih keloida.

Ključne reči: Penilni keloid, cirkumcizija, keloidni ožiljci.

10. Lokhande A, Wiblishauser M, Khubchandani J. Keloid and hypertrophic scar formation after male circumcision. Gulf J Dermatology Venerol. 2010; 17(1): 50-1.

11. Demirdover C, Sahin B, Vayvada H, Oztan HY. Keloid formation after circumcision and its treatment. J Pediatr Urol. 2013; 9(1): e54-6.

12. Xie LH, Li SK, Li Q. Combined treatment of penile keloid: A troublesome complication after circumcision. Asian J Androl. 2013; 15(4): 575-6.

13. Yong M, Afshar K, MacNeily A, Arneja JS. Management of pediatric penile keloid. Can Urol Assoc J. 2013; 7(9-10): e618-20.

14. Cinpolat A, Seyhan T, Rizvanovic Z, Demirturk P, Bektas G.. A very rare complication: keloid formation after circumcision and its treatment: case report. Turkiye Klin J. 2015; 23(4): 444-6.

15. Ozinko MO, Otei OO, Ikpi EE. Penile paediatric keloids: a rare presentation. Eur J Biomed Pharm Sci. 2015; 2(5): 33-7.

16. Sanal M, Haerter B. Keloid on the penis after circumcision: a rare complication. Clin Surg. 2017; 2: 1705.

17. Niessen FB, Spauwen PHM, Schalkwijk J, Kon M. On the nature of hypertrophic scars and keloids: a review. Plast Reconstr Surg. 1999; 104(5): 1435-58.

18. Halim AS, Emami A, Salahshourifar I, Kannan TP. Keloid scarring: Understanding the genetic basis, advances, and prospects. Arch Plast Surg. 2012; 39(3): 184-9.

\section{Correspondence to/Autor za korespondenciju}

Ahmad Sukari Halim

Reconstructive Science Unit, Hospital Universiti Sains Malaysia and School of Medical Sciences

Universiti Sains Malaysia, 16150 Kubang Kerian, Kelantan, Malaysia

email: ashalim@usm.my 